\title{
The Deleveraging of U.S. Households: Credit Card Debt over the Lifecycle
}

Helu Jiang, Technical Research Associate

Juan M. Sanchez, Research Officer and Economist

ggertsson and Krugman (2012) contend that "if there is a single word that appears most frequently in discussions of the economic problems now afflicting both the United States and Europe, that word is surely debt." These authors and others offer theoretical models that present the debt phenomenon as follows: The economy is populated by impatient and patient individuals. Impatient individuals borrow as much as possible, up to a debt limit. When the debt limit suddenly tightens, impatient individuals must cut expenditures to pay their debt, depressing aggregate demand and generating debt-driven slumps. Such a reduction in debt is called deleveraging.

Individuals younger than 46

deleveraged the most after the financial crisis of 2008.

The evolution of total credit card debt around the financial crisis of 2008 appears consistent with that sequence: Credit card debt increased quickly before the financial crisis and then fell for six years after that episode. Although credit card debt began to rise again in 2015, the total remains 20 percent below its 2009 peak. In this essay, we analyze credit card debt by borrower age group for the 2004-08 and 2008-15 periods to determine whether the sequence of events holds at the micro (household) level.

The data used are from the Federal Reserve Bank of New York Consumer Credit Panel/Equifax. The first figure shows total credit card debt ${ }^{1}$ of individuals 20 to 70 years of age. Credit card debt increased by approximately $\$ 114$ billion in the 2004-08 period, peaked in 2009, and then decreased by over $\$ 193$ billion in the $2008-15$ period. ${ }^{2}$

To better understand how individual credit card debt changed over the two periods, we calculate the share each age group contributed to the total changes. The results are presented in the second figure. In the 2004-08 period, credit card balances increased across all age groups. Most of the

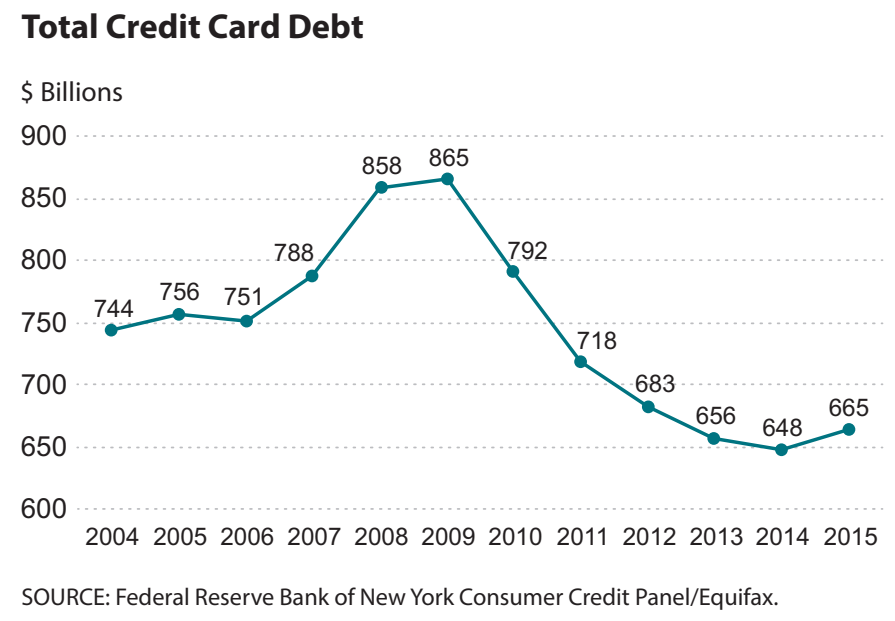

\section{Share of the Change in Total Credit Card Debt by Age Group}

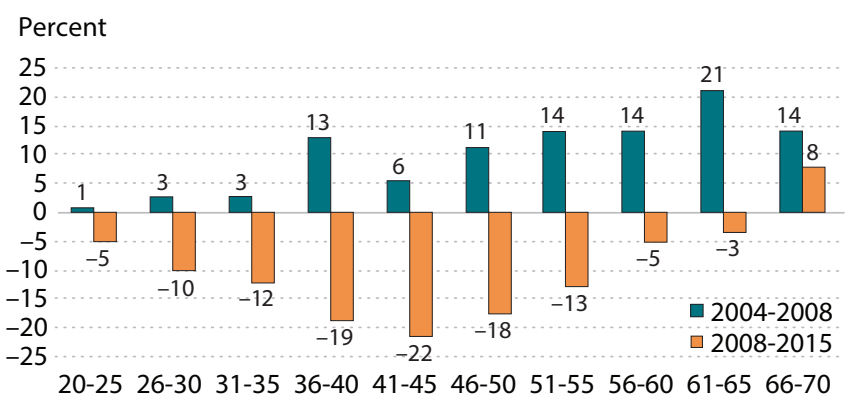

Age Group

NOTE: The share of the change for each age group is defined as the change in credit card debt for that age group divided by the absolute value of total debt; that is, share $\stackrel{\text { def }}{=} \frac{\left(x_{t 2}^{i}-x_{t 1}^{i}\right)}{\left|x_{t 2}-x_{t 1}\right|}$, where $x$ is total credit card debt, $x^{i}$ is credit card debt of a particular age group, and $|x|$ is the absolute value of $x$. SOURCE: Federal Reserve Bank of New York Consumer Credit Panel/Equifax.

increase-almost 50 percent-however, was driven by individuals 56 years of age and older. Remarkably, individuals younger than 46 years of age, who arguably need to borrow the most, accounted for only 25 percent of the increase in total debt. 
Deleveraging of credit card debt after the financial crisis of 2008 continued until 2015. Importantly, in clear contrast with the pre-crisis period (2004-08) when older individuals increased their credit card debt the most, younger individuals reduced theirs the most during the post-crisis (2008-15) period. Individuals 56 years of age and older accounted for virtually none of the decrease in credit card debt. For individuals 66 to 70, credit card debt actually increased. Strikingly, individuals younger than 46 accounted for 68 percent of the deleveraging.

These findings suggest that although the evolution of credit card debt at the aggregate level is consistent with the sequence of events described by Eggertsson and Krugman (2012), changes at the individual level are not. In particular, younger individuals-who contributed little to the precrises expansion of credit-deleveraged the most.

What accounts for the deleveraging by younger individuals? After the crisis, younger individuals, with arguably poor job prospects, decreased their debt and increased their savings. The deterioration of job prospects is well documented by Moscarini and Postel-Vinay (2016), who named it "the failure of the job ladder." The deterioration of jobs prospects, however, would not have affected older individuals, who had arguably already climbed the job ladder and thus did not need to deleverage. Thus, labor market changes may have caused the deleveraging. And what explains the period of credit expansion? It's possible that the relaxation of credit limits played a role. Of course, more evidence is needed to determine the accuracy of these possible explanations. Identifying the real factors that caused the deleveraging is important because policy recommendations may depend crucially on them.

\section{Notes}

1 The Equifax credit-reporting data include a nationally representative 5 percent sample of all adults with a Social Security number and a credit report. The credit card debt is called "bankcard" debt in the dataset. Since consumer credit profiles are recorded at the end of each quarter, credit card debt is not revolving.

2 Notice that the total differs from that of the United States because the data used here include only a sample of individuals. Actually, we use a subsample of the Federal Reserve Bank of New York Consumer Credit Panel/Equifax data.

\section{References}

Eggertsson, Gauti B. and Krugman, Paul. "Debt, Deleveraging, and the Liquidity Trap: A Fisher-Minsky-Koo Approach." Quarterly Journal of Economics, August 2012, 127(3), pp. 1469-513.

Moscarini, Giuseppe and Postel-Vinay, Fabien. "Did the Job Ladder Fail after the Great Recession?" Journal of Labor Economics, January 2016, 34(S1, Part 2), pp. S55-S93. 